\title{
ОСОБЛИВОСТІ ГІНГІВОГЛІФІКИ У ПАЦІЄНТІВ, ЩО ЗВЕРТАЛИСЯ НА ЛІКУВАННЯ У СТОМАТОЛОГІЧНУ ПОЛІКЛІНІКУ ЛЬВІВСЬКОГО МЕДИЧНОГО УНІВЕРСИТЕТУ
}

\author{
О.Р. Ріпецька, В.С. Гриновець, А.Ю. Бучковська, М.В. Ренка \\ ЛьВівський національний медичний університет ім. Данила Галицького
}

\begin{abstract}
При патології пародонта часто розвивається хвороблива зміна макрорельєфу ясен, яка супроводжується гіпертрофією чи рецесією ясен з оголенням коренів зубів та розвитком патології цементу. Макрорельєф контуру ясен ми характеризували терміном гінгівогліфріка.

Нами досліджено, що особливості контуру та макрорельєфу ясен можуть фрормувати аркадний, балонуючий, сплощений та змішаний типи гінгівогліфіки. При хворобах пародонта часто формується патологічний макрорельєф контуру ясен: змішаний $-8,56 \%$, сплощений - 6,29\%, балонуючий $-4,23 \%$, посилено-аркадний $-3,28 \%$. Знання особливостей гінгівогліфріки дозволяє краще планувати та прогнозувати лікування пацієнтів із патологією пародонта.

КлючоВі слоВа: патологія пародонта, маргінальний пародонт, гінгіВогліфріка, рецесія ясен.
\end{abstract}

При патології пародонта часто розвивається хвороблива зміна макрорельєфру ясен, яка супроводжується гіпертрофрією чи рецесією ясен 3 оголенням коренів зубів та розвитком патології цементу $[1,5]$, що погіршують перебіг хвороби, сприяючи інтенсивному утворенню мікробної платівки, інтоксикації маргінального (вінцевого) пародонта й підтримуванню в ньому запального процесу $[3,5]$. Виникає клінічна проблема не лише охорони цементу зуба від дії карієсогенних чинників порожнини рота, але й забезпечення високого ступеня його чистоти і гладкості з метою зменшення ризику утворення назубних відкладень [2-4].

Мета роботи - визначення частоти патологічних змін макрорельєфу ясен у пацієнтів, що зверталися на лікування у стоматологічну поліклініку Львівського медичного університету.

Матеріал та методи. Обстежено 405 осіб віком 18-45 років, що звернулись на лікування у стоматологічну поліклініку Львівського медичного університету. Серед обстежених пацієнтів відібрано 393 особи з ознаками патології пародонта. Із них у 57 осіб підтверджено хронічний генералізований пародонтит різних ступенів важкості. У обраної групи пацієнтів із патологією пародонта визначався індекс кровоточивості ясен, стан гігієни порожнини рота та макрорельєф вінцевого (маргінального) пародонта.

Результати досліджень та обговорення. В результаті проведених нами клінічних досліджень виявлено патологію пародонта у 219 осіб із 405 обстежених, що становить 54,24\%. У 174 пацієнтів $(42,97 \%)$ діагностовано хронічний генералізований пародонтит I-II ступенів важкості. Водночас у 102 пацієнтів $(26,0 \%$ із всіх пацієнтів, що звернулись на лікування) виявлена патологічна зміна макрорельєфу ясен, у тому числі їх рецесія, та, як наслідок, - оголення цементу кореня зубів.

При клінічному огляді всіх пацієнтів із патологічною зміною контуру ясен виявлено низький стан гігієни порожнини рота $(2,63 \pm 0,16)$ в індексному вираженні, високі показники у хворих кровоточивості ясен (I кр >1 у 70-80\%), зубних відкладень - 80-90\% та обов'язкові хворобливі ознаки стану маргінального пародонта (гіперемія, набряк, атрофрія, зміна контуру ясен, пародонтальні кишені, порушення зубоясенного з'єднання).

Внаслідок розвитку патологічної гінгівогліфіки і рецесії ясен у 76,2\% хворих відзначалось оголення цементу кореня і різної етіології цементопатії: пігментація, відкладення, клиноподібний дефрект, карієс. Встановлено, що за клінічною картиною у більшості обстежених пацієнтів виявлено запальні і дистрофрічні ураження (92,5\%), а у 7,5\% спостерігались лише атрофрічні зміни пародонта без запального процесу. Прояви лише дистрофрічного характеру без запальних змін зустрічалися у порівняно невеликої частини пацієнтів.

Рецесія ясен у міжапроксимальних ділянках призводила до утворення проміжків, сприятливих для розвитку зубної пластини та затримки залишків їжі. Особливий вид рецесії, так звані розщілини Стілмана, зустрічались на вестибулярній поверхні зубів. Частіше спостерігаються прості розщілини із розривом слизової оболонки ясен тільки в одному напрямі. Зустрічаються також складні розщілини із розривом слизової ясен у кількох різних напрямках. Довжина розщілин Стілмана коливалась від 1-2 до 5-6 мм і більше. Розщілини Стілмана існували як 
поверхневі десекти слизової оболонки ясен над неглибокими пародонтальними кишенями в ділянках оклюзійної травми, в той час як на інших ділянках кореня діагностувалися кишені більшої глибини.

Макрорельєф контуру ясен ми характеризували терміном гінгівогліфіка. Терміном гінгівогліфіка посилено-аркадний - 3,28\%. Внаслідок розвитку патологічної гінгівогліфіки і рецесії ясен у $20,38 \%$ хворих відзначалось оголення цементу кореня і різної етіології цементопатії: пігментація, відкладення, клиноподібний десект, демінералізація, карієс (див. табл.).

Частота гіперемії ясен, патологічної гінгіВогліріки та оголення цементу кореня зуба у пацієнтів стоматологічної поліклініки

\begin{tabular}{|c|c|c|c|c|c|c|c|}
\hline \multirow{3}{*}{$\begin{array}{l}\text { Кількість } \\
\text { хворих }\end{array}$} & \multicolumn{7}{|c|}{ Виявлено } \\
\hline & \multirow{2}{*}{$\begin{array}{c}\text { Зміна } \\
\text { кольору } \\
\text { ясен }\end{array}$} & \multirow[b]{2}{*}{ Гінгіворагія } & \multicolumn{4}{|c|}{ Типи патологічної гінгівогліфіки } & \multirow{2}{*}{$\begin{array}{c}\text { Оголений } \\
\text { цемент кореня }\end{array}$} \\
\hline & & & $\begin{array}{c}\text { Посилено- } \\
\text { аркадний }\end{array}$ & Сплощений & Балонуючий & Змішаний & \\
\hline Абс. & 241 & 160 & 13 & 25 & 17 & 35 & 82 \\
\hline$\%$ & 59,61 & 39,46 & 3,28 & 6,29 & 4,23 & 8,56 & 20,38 \\
\hline
\end{tabular}

у стоматології визначається утворений міжзубними сосочками і пришийковим краєм рельєф маргінальної частини ясен. Контур ясен має свої особливості, на які впливає їх біотип, а також фоома і положення зубів. Нами досліджено, що особливості контуру та макрорельєфу ясен можуть фрормувати аркадний, балонуючий, сплощений та змішаний типи гінгівогліфіки. Аркадний тип гінгівогліфіки характеризується високими міжзубними сосочками і зустрічається частіше при тонкому біотипі ясен та дещо більшій від середнього висоті зубів. Інший тип гінгівогліфріки зустрічається при низьких та широких зубах та товстому біотипі ясен. Фізіологічними варіантами нормальної будови вінцевого пародонта можуть посилюватися при патології пародонта.

Нами встановлено наступний розподіл типів патологічного макрорельєфу контуру ясен, що можна визначити терміном - гінгівогліфріка: змішаний $8,56 \%$, сплощений $-6,29 \%$, балонуючий $-4,23 \%$,
Висновки. У більшості обстежених осіб із патологією пародонта $(72,8 \%)$ було виявлено порушення фрізіологічного контуру ясен, тобто макрорельєфу вінцевого пародонта, зміна кольору ясен була у $59,61 \%$, 3 них у $39,46 \%$ хворих кровоточивість ясен різного ступеня. Встановлений такий розподіл типів патологічної гінгівогліфріки у хворих: змішаний $-8,56 \%$, сплощений $-6,29 \%$, балонуючий - 4,23\%, посилено-аркадний $3,28 \%$ хворих. Водночас у хворих на пародонтоз переважав сплощений тип гінгівогліфіки і рідше проявлявся посилено-аркадний тип. У хворих на генералізований пародонтит домінуючим за частотою вияву був змішаний тип гінгівогліфіки, який спостерігався приблизно удвічі частіше, ніж інші типи. Вміння оцінити особливості макрорельєфу вінцевого пародонта $\epsilon$ надзвичайно важливим у плануванні лікування пацієнтів із патологією пародонта та оцінці його результатів.

\section{Література}

1. Dorland's illustrated medical dictionary. - Philadelphia: W.B.Saunders. Company. - 2007. - 2689 c.

2. Carranza F.A. Clinical Periodontology. 8th ed. / F.A. Carranza, M.G. Newman. - Philadelphia: W.B. Saunders, 1996. -782 p.

3. Ріпецька О.Р. Оцінка поверхні цементу зубів в процесі усунення зубних відкладень і полірування / О.Р. Ріпецька, В.С. Кухта / / Новини стоматології. - 2000. - № 2 (23). - С. 59-60.

4. Монастирський В.А. Коагуляційні та некоагуляційні пародонтози / В.А. Монастирський, В.С. Гриновець. - Львів: Ліга-Прес, 2003. - 107 с.

5. Денега І.С. Альтернативний підхід у місцевому лікуванні хворих на хронічний генералізований пародонтит / І.С. Денега, О.Р. Ріпецька, В.С. Гриновець, І.С. Гриновець / / Експериментальна та клінічна стоматологія. -2017 . - № 1 (1). - Р. 10-14.

\section{О.Р. Рипецкая, В.С. Гриновец, А.Ю. Бучковська, М.В. Ренка}

\section{ОСОБЕННОСТИ ГИНГИВОГЛИФИКИ У ПАЦИЕНТОВ СТОМАТОЛОГИЧЕСКОЙ КЛИ- НИКИ ЛЬВОВСКОГО МЕДИЦИНСКОГО УНИВЕРСИТЕТА}

Заболевания пародонта часто сопровождаются патологическими изменениями макрорельефа маргинальных десен, их гипертрофией либо рецессией с обнажением корней зубов и развитием патологии цемента. Макрорельеф контура десен нами определен термином гингивоглифика.

Макрорельеф десен в норме может формировать следующие типы: аркадный, баллонирующий, плоский и смешанный. При болезнях пародонта часто формируется патологический макрорельєф контура десен: упло- 
щенный $-6,29 \%$, баллонирующий $-4,23 \%$, усиленно-аркадный $-3,28 \%$, смешанный $-8,56 \%$. Знание особенностей гингивоглифики позволяет лучше спланировать и спрогнозировать лечение пациентов с патологией пародонта.

КлючеВые слова: патология пародонта, маргинальный пародонт, гингиßоглифика, рецессия десен.

O.R. Ripetska, V.S. Hrynovets, A.Ju. Buchkovska, M.V. Renka

\section{PECULIARITIES OF THE GINGIVOGLYPHICS IN PATIENTS WITH PERIODONTAL PATHOLOGY TREATED IN THE CLINIC OF LVIV NATIONAL MEDICAL UNIVERSITY}

Characteristic signs of pathological gingival contour often develop in patients with periodontal pathology.

We examined 219 patients (18-45 years old) with different types of periodontal pathology. In 174 patients (26.6\% of examined persons) Chronic Generalized Periodontitis of I-II stages of heaviness was diagnosed. Changes in the physiological contour of the gums (that is macrorelief of marginal periodontium) were found in 102 of examined patients.

According to achieved data in patients with periodontosis flat type of gingival relief prevailed in I stage as well as in II stage of disease, two-three times rarely strenuously arcade type of gingival contour was observed. In patients with I stage of periodontitis all three types of pathological gingival contour (gingivoglyphics) were observed with the same frequency: flat, balloon-like, and combined, while in II stage of generalized periodontitis combined and strenuously arcade type of gingival contour dominated.

Because of the development of pathological gingival contour and recession of the gums, $72.5 \%$ of examined patients suffered from root denudation and different pathological conditions of roots cement structure pigmentation, demineralization, wedge-shaped defects, caries.

Periodontal dystrophy was observed in number of signs: recession of the gums (lowering of the level of marginal gingival), atrophy of interdental papilla with formation of pathological spaces between adjacent teeth, thinning, flattering paleness of the gums. Patients complained on gums tightening, itching, increase sensibility to thermal, mechanical and chemical irritants. Because of large interdental spaces, lot of plaque and calculus accumulated on teeth surfaces. We observed Stilman's clefts from 1-2 to 5-6 mm long.

According to our clinical investigations it was found out that in majority of patients $(83 \%)$ both inflammatory and dystophic changes were present, only $17 \%$ of patients had purely atrophic process in the periodontium without inflammation. In patients with Generalized Periodontitis and periodontosis, in whom dystrophic changes were accompanied by inflammation, clinical appearance was more expressed with redness, bleeding and suppuration from the pockets, thus hiding dystrophic signs.

We revealed following changes in gingivoglyphics in examined patients: flat $-6.29 \%$, balloon-like $-4.23 \%$, strenuously arcade type $-3.28 \%$, combined $-8.56 \%$.

Abovementioned changes of gingival contour represent different types and stages of periodontal pathology and their analyses helps periodontal specialist in choosing proper treatment plan and prognosis.

Keywords: periodontal pathology, marginal periodontium, gingivoglyphics, recession of the gums.

\section{Контактна інформація}

Ріпецька О.Р. - доцент кафедри терапевтичної стоматології Львівського національного медичного університету ім. Данила Галицького

Гриновець В.С. - доцент кафедри терапевтичної стоматології Львівського національного медичного університету ім. Данила Галицького

Бучковська А.Ю. - асистент кафедри терапевтичної стоматології Львівського національного медичного університету ім. Данила Галицького

Ренка М.В. - асистент кафедри терапевтичної стоматології Львівського національного медичного університету ім. Данила Галицького

Адреса для кореспонденції: 79010, м. Львів, вул. Пекарська, 69в 